\title{
The Effect of Investment Committee on the Financial Sector Performance of Saudi Financial Market in View of Vision 2030: A Panel Data Approach
}

\author{
Ebrahim Mohammed Al-Matari \\ Assistant Professor, Department of Accounting \\ College of Business, Jouf University, Aljouf, Kingdom of Saudi Arabia \\ Amran University, Yemen \\ E-mail: ibrahim_matri7@yahoo.com
}

Received: September 21, 2019 Accepted: November 9, 2019 Published: November 20, 2019

doi:10.5296/ijafr.v9i4.15570

URL: https://doi.org/10.5296/ijafr.v9i4.15570

\begin{abstract}
The investment committee is primarily a decision-making entity that aims to implement investment decisions taken by the company. In the framework of the powers conferred upon it by the board, the importance of this committee is highlighted and as such, in the present study, the primary aim is to examine the effect of investment on Saudi financial sector, an examination that is the first of its kind. The investment variable was measured by investment committee characteristic including, size, independence, meeting, commitment and allowance for session attendance. The study data was gathered from the annual reports of the financial firms spanning from 2014 to 2017. Panel data was used to conduct the hypotheses testing concerning the relationship among the variables of the investment commitment and the performance of the financial firms. Based on the findings, investment committee size and investment committee independence positively and significantly related with the performance of the firms. This study has several contributions to literature, particularly concerning information about the importance of investment committee. In addition, this study is clarified our understanding concerning best practices of corporate governance structure existing in Saudi financial listed companies.
\end{abstract}

Keyword: Investment committee, Financial sector, Saudi Vision 2030 


\section{Background of the Study}

As mentioned, this study aims to examine the main variables of investment committee that have the potential of improving the performance of the financial sector in Saudi Arabian market. This study used FGLS regression to test the hypothesis regarding the relationship between investments variables and financial company's performance. Moreover, this study obtained data from the annual reports of the companies and the data Stream for four years (2014-2017). Finally, this study is unique in that it extends previous literature related to corporate governance characteristics, particularly investment committee variables.

The major authority that establishes the objectives and corporate policies on corporate investment is the Investment Committee. In some businesses, the Investment Committee is the one that makes decisions and delegate some decisions to consultants or specific firms/individuals. While the committee unarguably holds the author and responsibility to make decisions of this caliber, its firms task is to adopt a written operating policy, defining committee members, the structure of meetings and policies on meeting attendance. In addition, the members of the committee decide on how to obtain investment information and to present it to the board.

Performance reflects the successful ventures of corporate entities at a specific time period and as such, performance measures has been the topic of examination of a large portion of literature as determining such measures can present a picture of the performance development of firms throughout periods and compare it with their market competitors. Firm performance is significantly affected by corporate governance (CG). More importantly, if the organization's functions are aligned with those of the system of governance, this will bring about investments and company capital and funds, supporting its pillars and leading to enhanced performance. In relation to the above, effective mechanisms of corporate governance work towards protecting the firm against financial chaos and facilitating the developments that it requires. Presently, the firms are affected by corporate governance mechanisms such effects have been examined in literature in an extensive manner (Al-Matari et al., 2014).

Added to the above, firm value is described as the assets that the firm has that are attributed to the shares that the shareholders own (Rouf, 2011). In this regard, the company's performance can be gauged in terms of its financial statement and records and thus, financial information disclosure provides useful information to financial statement users. As subsequence, a good performing company will support management to provide a quality disclosure of such information (Herly \& Sisnuhadi, 2011).

There are innumerable ways that have been proposed for the financial performance measurement, and accounting based measurement is one of them. Accounting-based measurement takes on many types including, Return on Equity (ROE), Return on Assets (ROA), Return on Investment (ROI), Return on Sales (ROS), Operating Cash Flow (OCF), Operation Profit (OP), Profit Margin (PM), Earnings per Share (EPS), Return on Capital Employed (ROCE), Cash to Assets (CTA), Growth in Sales (GRO), Expense to Assets (ETA), Expenses to Sales (ETS), Labor Productivity (LP), Sales to Assets (STS), Cost of Capital 
(COC), Profit per Employee (PPE), Return on Revenue (ROR), and finally, Return on Fixed Assets (ROFA). Majority of the above measures have been used among studies dedicated to examining corporate governance and on the basis of the argument as to suitable methods to be utilized, researchers have generally suggested to examine the corporate governance determinants through accounting-based measures (e.g., Khatab et al., 2011; Al-Matari et al., 2014).

Based on the findings of empirical studies (e.g., Abdallah \& Ismail, 2017; Ahmed \& Hamdan, 2015; Al-Bassam et al., 2018; Al-Hadi, Hasan \& Habib, 2016; Al-Janadi, Rahman \& Alazzani, 2016; Al-Obaidan, 2008; Mersni \& Bin Othman, 2016; Ramly \& Nordin, 2018), corporate governance mechanisms including board of directors, audit committee and their characteristics, ownership structure, internal audit and risk committee characteristics, are significant to the development of firms performance in both nation types (developed and developing). Despite the significant findings, the investment committee characteristics (size, independence, meeting, commitment to meetings and allowances for session attendance) and their relationship with the performance of financial firms have been underplayed in literature. Therefore, the present study is conducted to mitigate the literature gap.

In the present section, the paper presents the underpinning theories used in the study. Despite the innumerable theories that have been utilized by researchers in corporate governance literature including agency theory, resource dependence theory, institutional theory, transaction cost theory, stewardship theory, stakeholder theory, ethical theories, political theory, and tournament theory, the present study adopted extensively employed ones namely, the agency theory, the resource dependence theory and tournament theory. All three theories have been validated by current studies. On the basis of Al-Matari et al.'s (2012) recommendation theory testing in a study of firm performance using stakeholder theory, stewardship theory, and resource dependence theory, can provide new information and value to the literature under examination. This study considers the underpinning theories (resource dependence theory, agency theory and tournament theory) to be appropriate to explain the study variables.

Vision Saudi Arabia 2030 is the post-oil plan for the Kingdom of Saudi Arabia, announced on $25^{\text {th }}$ April 2016. Saudi Arabia focused its ambitious plan on several points such as, sovereign fund, freedom from oil, Aramco offering of stocks in the market, green card, thirty million pilgrims, employment and the private sector, military industry, housing and projects and anti-corruption. Based on that, the financial sector development program is one of the twelve executive programs launched by the council for economic affairs and development to achieve the objectives of Vision 2030. The program seeks to develop the financial sector as a diverse and effective financial sector to support the development of the national economy, stimulate savings, finance and investment, to address and resolve challenges. Moreover, this sector supports the development of the national economy and contributes to the achievement of the objectives of other vision programs.

Economic theory suggests that a more efficient and diversified financial system is an important requirement for economic growth, in that economic growth cannot be achieved 
without production. Financial broker facilitates the transition of capital to producers, which helps economic growth, and in turn, the development of the financial system. Meanwhile, the evolution of the financial system contributes to reducing the costs of information, transactions, monitoring and follow-up. On the other hand, the knowledge system stimulates investment by identifying and financing business opportunities, and to mobilize savings and monitor the actions of managers. The overall result leads to the improvement of the efficiency of human resources, which contributes, to the growth of the economy. Macroeconomic stability is therefore very important for the growth of financial sector services owing to its contribution to the development of more transparent facilities and the development of more quality laws for the activity of the financial sector. This requires, inter alia, government rules and regulations that take precautions for risks and the like, and require effective credit rights and legal application. As a result of this economic stability, Saudi Arabia has sought to give this sector a great importance in its Vision 2030.

Finally, based on the importance of the financial sector and investment factors according to the Vision of the Kingdom of Saudi Arabia, this study focused on examining the relationship between investment committee characteristics including size, independence, meeting, commitment to meetings and allowances for session attendance and the performance of financial sector banks and insurance companies for a specific period of time, from 2014 to 2017.

\section{Literature Review and Proposed Hypotheses}

\subsection{Investment Committee Size}

The relationship between the characteristics of investment commitment and the performance of firms has not been extensively examined in literature and the present one appears to be the first of its kind in a specific context. The study provides a review of literature focused on the investment committee size-firm performance relationship, with the former measured by its numbers of members.

In relation to the agency theory, the higher the number of board members, the more the board ineffectiveness level will rise, as the members will have the tendency to waste time on reaching the right decision. Meanwhile, Jensen and Meckling (1976) argued that a large-sized committee consists of different perspectives. On the other hand, coordination and communication through the decision making issues could prevent performance with increased number of directors, and when extra members exist - and thus, coordination is countered with diversity (Rouf, 2011; Yermack, 1996).

More specifically, when it comes to the few studies dedicated to the characteristics of investment committee, Shaver (2005) indicated that a large committee had notable diffusion of responsibilities, which promotes social loafing and fractionalization of groups, and eventually, lower commitment placed on the strategies changes by the members. Based on the resource dependence theory perspective, the board of directors (in this case, committee), the board can acquire resources through its members' connection with other firms and this notion was supported by Pfeffer (1972), Provan (1980) and Zald (1967). Similarly, the theory 
proceeds to explain that large-sized boards can facilitate optimum corporate performance because of the different skills, knowledge and expertise it holds during the discussion in the boardroom. Such boards also provide diversity that can help in resources acquisition and in mitigating risks in the environment as explained by prior studies (e.g., Goodstein et al., 1994; Nazli Anum, 2010; Pearce \& Zahra, 1992; Pfeffer, 1987). Consequently, the addition of extra members to the board will render it more useful as more experience and knowledge is also added to the mix to reach an informed decision, and as such, big-sized committees assist in boosting the performance of the firm.

Added to the above, boards that are large in size present more diversity in their different relationships to the external environment, with which they are able to acquire the required resources and innovation to establish corporate policies with and promote efficient processes and activities (Goodstein et al., 1994; Nanka-Bruce, 2011).

Along a similar line of study, large-sized boards according to Chaganti et al. (1985) and Dalton et al. (1998), exceed the performance of small-sized ones because of the possessed experienced of the members that can precipitate informed decision-making. Large-boards are also capable of steering clear of corporate and business failures (Dallas, 2001) and of urging management to bring about lower debts costs for enhanced performance (Anderson et al., 2004) and based on the above discussion of literature findings, the study proposes that;

\section{$H_{1}$ : investment committee size improves firm performance.}

\subsection{Investment Committee Independence}

Independence is another investment committee characteristic that is under examination in the present study and generally independence is gauged through the number of committee members that are independent. However, this variable has been under-studied in empirical studies and thus, the present study attempts to mitigate the literature gap by focusing on the investment committee's independence relationship with the performance of firms.

With regards to the few theoretical findings in literature concerning the above relationship, the independence of the committee members assists in firms monitoring effectiveness and in reaching informed decisions to ensure the firms' positive financial performance as evidenced by Johnson et al. (1993) and Stanwick and Stanwick (2010). In this line of argument, Hsu and Petchakulwong (2010) revealed that independent members are not easily swayed by the majority shareholders, management and other related individuals and entities and because of this, their concentration is fully focused on overseeing management and not satisfying their self-serving needs. Such unrelenting focus is supported by their lack of connection with management, whether economic or psychological relationships.

On the viewpoint of agency theory, external board members could lend support to the value of the firm through their experience and monitoring activities (Berle \& Means, 1932; Fama \& Jensen, 1983). Similarly, the directors reasoning can safeguard the interests of the shareholders through their oversight and prior and present experiences (Mace, 1986).

Viewed from the stance advocated by the resource dependence theory, the integration of 
independent members with their dependent counterparts can provide various resources to the committee, after which the performance of the firm is improved. Also, the experience and knowledge brought in by the independent members can bring about decisions in a timely and informed manner as explained in Pearce and Zahra (1992) and Pfeffer's (1987) studies. Hence, in the present study, the investment committee independence is proposed to have the following relationship with the performance of firms;

H2: There is a significant relationship between investment committee independence and firm performance.

\subsection{Investment Committee Meeting}

The meeting of the investment committee is, in essence, the third factor of the characteristics of investment committee, upon which the board independence hinges. The frequency of board meetings can lead to enhanced firm performance with the board having increasing opportunities to oversee and review the performance of management (Hsu \& Petchsakulwong, 2010). The investment committee meeting is measured through the annual meeting frequency.

Studies in literature showed that the higher the meetings frequency, the higher will be the level of positive achievement (e.g., Jackling \& Johl, 2009; Lipton \& Lorsch, 1992). This was supported by Kyereboah-Coleman (2006), who revealed that the time of the board meeting can be manipulated in a way that will improve the effectiveness of the committee. According to the findings of Kyereboah-Coleman (2007), frequent meeting of the committee members could boost their creativity in thinking of strategies to improve the performance of firms and to satisfy the requirements of shareholders. This supports Khanchel's (2007) and Shivdasani and Zenner's (2002) findings concerning the need for the committee to frequently have meetings, particularly when higher supervision and monitoring are called for.

The resource dependence theory also advocates that the relationship between corporate governance and performance is in turn, related to the board activity level, gauged by the meetings frequency. Based on the theory, meeting brings about evaluation and pursuant of resolving issues that crop up in the business processes.

In this line of argument, frequent meetings are expected to lead to enhanced performance. As for the agency theory, it posits that the members of the board have to be inactive as their high activity reflects innumerable issues that have to be resolved to assist the adverse performance of the firm (Jensen, 1993).

However, despite the logic behind the above argument, the frequency of meetings should not supersede the quality of meetings and more often than not, frequent annual meetings are viewed as the board playing an operating role as opposed to an oversight one - the latter of which should be where its focus is placed on (governing management) and not the former (managing the firm). Hence, this study examines the relationship between investment committee meeting and firm performance, with the assumption that board meeting frequency can enhance the performance of the firm. On the basis of the findings in literature and the underpinning theories, which indicate contrast, the following hypothesis is formulated to be 
tested;

H3: There is a significant relationship between investment committee meeting and firm performance.

\subsection{Commitment of Investment Committee to Meetings}

The commitment of the investment committee is crucial factor in business evaluation is required to meet the firm's target and to resolve problems. The board commitment is gauged through the meeting attendees, particularly the ratio of attendance of all the members of the investment committee during a specific year.

Meeting attendance of the members of the committee represent how serious they take their work and assess the issues for their resolution and for informed decisions in order to meet objectives (firm and investors). For further elaboration, timely work tasks completion supports the confidence of the investors in the firm as it represents the commitment of the firm towards value making and appealing to potential investors. Stated clearly, commitment reflects that the committee evaluates, values, oversees and promotes excellence of business and investors' value (Al-Rimawi, 2001).

Viewed from the perspective of the agency theory, separation of jobs promotes independence among members and paves the way for effective decision-making and informed decisions. It provides oversight and assessment of firms' integrity of reports for all the stakeholders without withholding any information (Jensen \& Meckling, 1976). Board commitment relays the obligation of the members and their efforts to enhance firm performance as argued by Pfeffer and Salancik (1978).

On the other hand, lack of members' commitment is indicative of their lack of awareness of procedures, responsibilities and tasks and based on prior relevant studies of Garg 92007) and Shao (2010), board diversity, including board commitment, should be examined for its variations and effects on the performance of firms.

In the Kuwaiti case, the relationship of corporate governance and firm performance was investigated in Al-Matari et al.'s (2012) study and the authors suggested the role of board diversity as a moderating variable between the relationship between firm performance and corporate governance as literature provided findings remained unconfirmed. Al-Matari et al. (2012) also stressed on the need to examine the relationship of board experience and qualification, with the performance of the firm. Thus, the present study focused on the investment committee's commitment to meetings as a moderating variable. The study proposes the following hypothesis for testing;

H4: There is a significant relationship between commitment of investment committee too meetings and firm performance.

\subsection{Session Attendance Allowance}

The current global financial crisis brought about the demise of several global commercial entities, after which lessons were reaped by those that have been affected. Firms took 
recourse in developing suitable strategies for the investment committee to adopt. It appears that investment committee has become known as one of the significant company elements that contribute to maximizing value of shareholders and profitability, while maintaining the economic stability of the country. Hence, session attendance allowance is viewed in this study as one of the top significant variables in all sectors, creating a competitive environment and assisting enterprises in objectives achievement and ultimately, continuous performance enhancement.

It is important for management to integrate the procedures and conditions under which the allowance is given and the indulgence and courtesy of presenting the allowance to deserving people. This will lead to boosting employees' morale along with providing other advantages like motivating employees to take on business innovation, developing a competitiveness spirit in the workplace, and assisting the organization in modernizing goals, achieving goals, and facilitating workers teamwork for continuous exposure.

However, despite the significance of the variable, it has yet to be examined extensively in literature in both developing and developed nations. Therefore, the present study is one of a kind in that it addresses the variable and its impact on the financial sector firms' performance. The study is also a pioneering one in that it focuses on the effect of the investment commitment on the Saudi financial sector firms performance. Because the studies dedicated to the relationship between session attendance allowance and corporate performance are minimal, so no comparison can be made, the following hypothesis is formulated to be tested;

H5: There is a significant relationship between session attendance allowance and firm performance.

\section{Research Methods}

\subsection{Data Collection}

The study data about investment committee and firm performance was obtained from the annual reports of Saudi listed firms trading in the stock market. In particular, the data about FP (ROE) was gathered from Data Stream. The sample consisted of 196 financial firms for the years 2014 to 2017.

\subsection{Unit of Analysis}

The study's unit of analysis is Saudi listed firm within which the relationships of the study variables are examined at the corporate level.

\subsection{Model Specification}

The findings obtained by the model was through the use of FGLS method (refer to Table 4). The model comprises of CG variables to shed light on the linear relationship between investment variables and firm performance among listed firms in Saudi Arabia.

$$
\begin{aligned}
& \mathrm{ROE}=\beta 0+\beta 1 \text { INVSSIZE }+\beta 2 \text { INVSNONEX }+\beta 3 \text { INVSMET }+\beta 4 \text { INVSCOMIT } \\
& +\beta 5 \text { INVSASATT }+\beta 6 \text { FIMSI }+\beta 7 \text { LEVGE }+\varepsilon i
\end{aligned}
$$




\section{$\triangle 1$ Macrothink}

Where are:

ROE: Retune of Equity

INVSSIZE: Size of investment committee

INVSNONEX: Independence of the investment committee

INVSMET: Frequency of investment committee meetings

INVSCOMIT: Investment committee commitment to meetings

INVSASATT: Session attendance allowance

FIMSI: Firm size

LEVGE: Leverage

Ei: Error

\subsection{Measurement of the Variables}

This section explains the measures of dependent, independent and control variables. The measurements are summarized and listed in Table 1.

Table 1

\section{Variable Abbreviation Operationalization}

\section{Dependent Variable}

Return On Equity ratio ROE ROE measurement is obtained by calculating the net income of the shareholders' equity.

\section{Independent Variables}

Investment Committee Size (number)

INVECOSIZ $\mathrm{E}$

Conceptualized as the total number of members in the investment committee

Investment Committee INVECOIND Conceptualized as the proportion of independent Independence (ratio) $\quad \mathrm{R} \sim \mathrm{O}$ members of the investment committee

\begin{tabular}{llll}
$\begin{array}{l}\text { Investment Committee } \\
\text { Meetings } \\
\text { (number) }\end{array}$ & $\begin{array}{l}\text { INVECOME } \\
\text { FING }\end{array}$ & $\begin{array}{l}\text { Conceptualized as the annual number of } \\
\text { meetings }\end{array}$ \\
\hline $\begin{array}{l}\text { Investment Committee } \\
\text { Commitment }\end{array}$ to OMVCOMC & $\begin{array}{l}\text { Conceptualized as the proportion of members of } \\
\text { the investment committee that are meeting } \\
\text { attendees }\end{array}$ \\
Meetings (ratio) & &
\end{tabular}


Session Attendance INVECOMA Conceptualized as the total amount received by Allowance $(\log ) \quad$ TT $\sim \mathrm{G}$ the investment committee members for being meeting attendees

\section{Control Variables}

Firm size

FIRMSIZE
Conceptualized as the $\log$ of the total assets of the firm

Leverage

LEVERAGE

Conceptualized as the total debts divided by total assets

\subsection{Sample Distribution}

Panel dataset from 49 (196 observations) financial listed firms in Saudi Tadawul was used for a four-year span (2014-2017). The sample frame structure was confined to financial firms as non-financial ones are governed by specific laws that may influence the study variables relationships.

\section{Results and Discussion}

\subsection{Descriptive Statistics}

The obtained descriptive analysis results displayed in Table 2, shows that the mean of Return on Equity Ratio (ROE) of Saudi financial firms is 0.268 , the minimum value is 0.040 and the maximum value is 0.909 . The results from the table 2 also show that the investment committee size (INVECOSIZE) of the Saudi financial firms has a mean value of four members, the minimum value of which is 2 and the maximum is 7 . As for the investment committee independence (INVECOINDR-O), it obtained a mean value of 59\%, with zero as the minimum value and 1 as the maximum value. This result shows that the committee in the Saudi stock market financial firms consists of both executive and non-executive members.

From Table 2, it is also evident that the mean of investment committee meetings frequency (INVECOMETING) is four times annually, with the minimum being 1 and maximum being 7 times a year. With regards to the investment committee commitment to meetings (INVECOMCOME-O), the results in Table 2 show the mean value to be $92 \%$, with the minimum value of $44 \%$ and maximum value of $100 \%$.

Moreover, the session attendance allowances (INVECOMATT-G) HAD A MEAN VALUE OF $4.4 \%$, a minimum value of 3.4 and a maximum value of 5.3 as tabulated in Table 2 . Lastly, firm size variable (FIRMSIZE) obtained a mean of 6.5, a minimum of 4.990 and a maximum of 8.653 (refer to Table 2) and leverage (LEVERAGE) obtained a mean of 0.391, as the minimum is 0.003 and the maximum value is 0.959 (refer to Table 2).

The descriptive statistics detailed results are presented in Table 2. 
Table 2

\begin{tabular}{|c|c|c|c|c|c|}
\hline Variable & Obs & Mean & Std. Dev. & Min & $\operatorname{Max}$ \\
\hline 1- Return On Equity ratio (ROE) & 196 & 0.267 & 0.168 & 0.040 & 0.909 \\
\hline $\begin{array}{l}\text { 2- Size of investment committee } \\
\text { (INVECOSIZE) }\end{array}$ & 196 & 3.597 & 0.755 & 2.000 & 7.000 \\
\hline $\begin{array}{l}\text { 3- Independence of the investment } \\
\text { committee (INVECOINDR O) }\end{array}$ & 196 & 0.586 & 0.196 & 0.000 & 1.000 \\
\hline $\begin{array}{l}\text { 4- Frequency of investment } \\
\text { committee } \\
\text { (INVECOMETING) }\end{array}$ & 196 & 3.582 & 1.488 & 1.000 & 7.000 \\
\hline 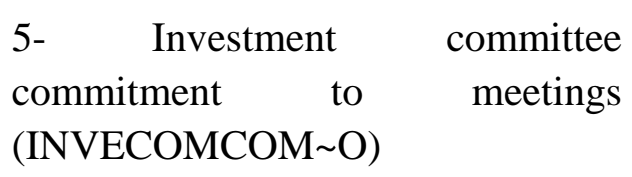 & 196 & 0.914 & 0.391 & 0.444 & 1.000 \\
\hline $\begin{array}{l}\text { 6- Session attendance allowance } \\
\text { (INVECOMATT } \sim \mathrm{G})\end{array}$ & 190 & 4.431 & 0.417 & 3.477 & 5.352 \\
\hline 7- Firm size (FIRMSIZE) & 196 & 6.540 & 1.031 & 4.990 & 8.653 \\
\hline 8- Leverage (LEVERAGE) & 196 & 0.391 & 0.375 & 0.003 & 0.959 \\
\hline
\end{tabular}

\subsection{Pearson Correlation}

The Pearson Correlation analysis results, obtained from the study variables namely investment committee characteristics and corporate performance of Saudi financial listed firms for four years (2014-2017), are presented in Table 3. The independent and dependent variables correlation matrix indicate no significant correlations among the independent variables, as the entire correlations did not exceed 0.80 . This is aligned with the recommendation provided by Gujarati (2009), who stated that correlation values should not be above 0.80 in order to confirm the non-existence of multicollinearity issue.

Table 3. Pearson correlation $(n=196)$

\begin{tabular}{llllllllll}
\hline Variable & 1 & 2 & 3 & 4 & 5 & 6 & 7 & 8 \\
\hline
\end{tabular}

1- Return On Equity

ratio (ROE) $\quad 1.000$ 
2- Size of investment

committee

(INVECOSIZE) $\quad-0.005 \quad 1.000$

3- Independence of

the investment

committee

$\begin{array}{llll}(\text { INVECOINDR O) } & -0.014 & -0.117 & 1.000\end{array}$

4- Frequency of

investment committee

meetings

$\begin{array}{lllll}\text { (INVECOMETING) } & -0.049 & 0.011 & -0.295 & 1.000\end{array}$

5- Investment

committee

commitment to

meetings

$\begin{array}{llllll}(\text { INVECOMCOM O) } & -0.061 & -0.119 & -0.070 & 0.026 & 1.000\end{array}$

6- Session attendance

allowance

$\begin{array}{lllllll}(\text { INVECOMATT G) } & -0.107 & 0.231 & 0.194 & 0.309 & 0.318 & 1.000\end{array}$

$\begin{array}{lrrrrrrrr}7- & \text { Firm } & \text { size } & & & & & & \\ (\text { FIRMSIZE) } & & -0.400 & 0.267 & 0.115 & 0.032 & 0.244 & 0.491 & 1.000\end{array}$

8- Leverage

$\begin{array}{lllllllll}(\text { LEVERAGE) } & -0.515 & 0.188 & 0.149 & 0.128 & 0.134 & 0.396 & 0.680 & 1.000\end{array}$

\subsection{Checking the Multicollinearity}

Multicollinearity was referred to Hair et al. (2010) as the level to which the variable's impact can be explained by other variables in the model. As the multicollinearity increases, the difficulty in the interpretation of the effects of all the variables also increases. Hence, this study conducted tolerance value and VIF tests in order to confirm whether or not multicollinearity exists among the variables. Hair et al. (2010) referred to tolerance vale as the variability of the variable that other variables failed to explain, whereas VIF is its antithesis test.

The variables tolerance values presented in Table 4, varied from 0.443 to 0.803 , whereas the values of VIF varied from 1.25 to 2.26 . The values show that the tolerance values all exceeded 0.1 , while the VIF values remained less than 10 , which meets the rule of thumb established by Hair et al. (2010). The values of both tolerance and VIF of the variables fell 
into the recommended range, confirming the absence of multicollinearity issue.

Table 4. Multicollinearity Test

\begin{tabular}{lll}
\hline Variable & VIF & $\mathbf{1 / V I F}$ \\
\hline FIRMSIZE & 2.26 & 0.443 \\
\hline LEVERAGE & 1.94 & 0.514 \\
\hline INVECOMATT G & 1.90 & 0.527 \\
\hline INVECOMETING & 1.41 & 0.707 \\
\hline INVECOINDR O & 1.38 & 0.727 \\
\hline INVECOMCOM O & 1.28 & 0.784 \\
\hline INVECOSIZE & 1.25 & 0.803 \\
\hline Mean VIF & 1.63 & \\
\hline
\end{tabular}

Note: INVECOSIZE: Size of investment committee, INVECOINDR O: Independence of the investment committee, INVECOMETING: Frequency of investment committee meetings, INVECOMCOM O: Investment committee commitment to meetings, INVECOMATT G: Session attendance allowance, FIRMSIZE: Firm size, LEVERAGE: Leverage.

\subsection{Multiple Linear Regression Analysis}

\subsubsection{Tests of Heterokedasticity and Autocorrelation}

One of the general violations in regression analysis involving cross-sectional data is the existence of heteroscedasticity as emphasized by Hair, Black, Babin and Anderson (2013). Such an issue could lead to over-exaggerated values of $t$ and $f$, which could lead to erroneous rejection of null hypothesis. This indicates that the variation of in the dependent variable is not explained by any of the independent ones, limiting the impacts of the regressors. Therefore, this study made use of Breusch and Pagan's (1979) test and Cook and Weisberg's (1983) test to detect heteroscedasticity presence.

Owing to the limitation of the inference of data concerning to a distinct industry type to a specific behavior, FGLS regressions was used in this study and based on Baltagi's (2008) study, a fixed-effects model can be investigated according to the results of the diagnostic examination test. Moreover, this study also made use of the Hausman specification test to justify the firm's effects as opposed to random effects (prob<chi ${ }^{2}$ less than .05). This is because of the insignificant differences found in the firms, which would reject the null hypothesis and as such, the study adopted fixed effects regression as suggested by Gujarati 


\section{MIN Macrothink}

International Journal of Accounting and Financial Reporting

ISSN 2162-3082

2019, Vol. 9, No. 4

(2009). Added to this, because of autocorrelation, the study employed a cross-sectional time-series FGLS regression that entailed panels, heteroskedastic, corr (independent) (Xtgls) rather than fixed effects regression as Quinonez, Saenz and Solorzano (2018) mentioned in their study.

The empirical results are tabulated in Table 5, and from the table, size of investment committee and independence of investment committee were both found to have positive significant relationships with corporate performance of Saudi financial firms. In contrast, frequency of investment committee meetings and lastly, session attendance allowance were not found to have any significant effects with the same.

\section{Evaluation of the Models}

Following the thorough testing and confirmation of the assumptions of the regression analysis, the next step involved running the regression analysis through State to investigate the predictive power of the characteristics of investment committee (i.e., size, independence, committee meetings frequency, commitment to meetings, and session attendance allowance) and their impact on the performance of Saudi financial firms. The primary aim behind this test is to determine each independent variable's predictive power towards the dependent one. Thus, the FGLS time-series regression was deemed appropriate and was carried out, after which, based on the obtained results, two of the hypotheses were supported, while the other $r$ three were rejected. The discussion of results is presented in the next section.

Table 5. Cross-sectional time-series FGLS regression $(n=196)$

\begin{tabular}{|c|c|}
\hline Variable & Model ROE \\
\hline & $0.011 * *$ \\
\hline \multirow[t]{2}{*}{ Size of investment committee (INVECOSIZE) } & $(1.95)$ \\
\hline & $0.121 * * *$ \\
\hline Independence of the investment committee (INVECOINDR O) & $(3.41)$ \\
\hline $\begin{array}{l}\text { Frequency of investment committee meetings } \\
(\text { INVECOMETING) }\end{array}$ & $\begin{array}{l}0.000 \\
(0.986)\end{array}$ \\
\hline \multirow[t]{2}{*}{$\begin{array}{l}\text { Investment committee } \\
\text { (INVECOMCOM O) }\end{array}$} & $\begin{array}{l}0.036 \\
(0.94)\end{array}$ \\
\hline & 0.017 \\
\hline Session attendance allowance (INVECOMATT $\sim \mathrm{G}$ ) & $(0.446)$ \\
\hline
\end{tabular}




\begin{tabular}{ll}
\hline Leverage (LEVERAGE) & $\begin{array}{l}-0.257^{* * * *} \\
(-13.67)\end{array}$ \\
\hline Prob > chi2 & $0.000^{* * *}$ \\
\hline Wald chi2(6) & 712.78 \\
\hline cons & $0.224 * * *$ \\
& $(3.24)$ \\
\hline
\end{tabular}

Notes: $\mathrm{t}$ statistics in parentheses $* \mathrm{p}<0.05, * * \mathrm{p}<0.01, * * * \mathrm{p}<0.001$

\section{Discussion of Results}

This section is dedicated to the discussion of the results of hypotheses testing relating to the study variables namely investment committee characteristics including size, independence, committee meetings frequency, committee's commitment to meetings and session attendance and their impact on the performance of Saudi listed financial firms.

Aligned with the assumptions of the resource dependence theory, the results obtained indicated a significant and positive relationship between investment committee size and corporate performance of the financial firms in Saudi Arabia. This result supported hypothesis $\mathrm{H} 1$ and it reveals that the investment committee size has a role in performance enhancement. The result is also consistent with the Code of Corporate Governance in Saudi Arabia (2005), which mandated listed firms to select board members to oversee the company operations and to reach informed decisions pertaining to the maximization of the shareholders' wealth.

Moving on to the investment committee's independence, which is another important characteristics of the investment committee and its role in the companies' performance, aligned with the agency theory and the dependence theory, it is a must to establish monitoring mechanisms to protect shareholders from the self-serving behaviors of managers. In this regard, majority of the board's external directors positively impacts the performance of the firm. In this case, the result is aligned with the assumptions of both theories as well as the stipulations of the Code of Corporate Governance that independence of the members of committee has a key role in the companies' performance. The result supports the proposed hypothesis $\mathrm{H} 2$.

The frequency of investment committee meetings is also another significant characteristic of the committee. Generally speaking, the effectiveness of the board, committee efficiency is reflected by meeting frequency in the hopes of enhancing performance. The underpinning 
theories namely agency theory and resource dependence theory advocates the same argument and thus, a significant relationship is assumed between the meeting frequency of investment committees and the performance of financial firms in Saudi Arabia. Nevertheless, based on the results obtained, no significant relationship was found between investment committee frequency of meetings and corporate performance, which means hypothesis $\mathrm{H} 3$ is rejected. This result may be attributed to the notion that board meeting does not always reflect enhanced firm performance as the meetings often become frequent only when the members of the committee need to resolve several issues (Jensen, 1993).

The commitment of the investment committee to meetings is another examined characteristic of the committee in this study. The study assumes it to be a significant variable for business performance evaluation. The committee's is committed to achieving the firm objectives and to resolving issues and such commitment is gauged using the meeting attendees. More specifically, the commitment is measured by the ratio of the meeting attendees and it is expected to positively impact the strategy, policy and decision-making process of the firm. However, in this case, the result is not significant and thus, hypothesis $\mathrm{H} 4$ is rejected.

Finally, prior literature on session attendance allowance showed a significant relationship between the variable and corporate performance. But based on the obtained results (refer to Table 5), a positive insignificant result was found between session attendance allowance and corporate performance, which means hypothesis $\mathrm{H} 5$ is also rejected.

\section{Conclusion and Implications}

Indubitably, the investment committee's characteristics are important in appealing to investments directed towards enhancing the countries' economic value but in the present study, only a few studies were found to be dedicated to the topic and thus, the study is among a few that tackled the issue. In this regard, the study contributes to literature concerning the importance of investment committee's characteristics in their role in enhancing corporate performance of Saudi financial firms.

The study is a pioneer study that examined corporate governance, particularly the impact of investment committee's characteristics namely size, independence, meetings frequency, committee's commitment to meetings and session attendance allowance, on the Saudi financial firms performance for a four-year span. The study employed FGLS regression to examine and independent and dependent variables' correlations. Based on the findings, the investment committee's size and its independence significantly and positively related to the Saudi financial firms' performance. Contrastingly, the investment committee's meeting frequency, committee to meetings and session attendance allowance were found to be positively related to such performance but the relationship was not significant.

More importantly, this study is a unique one in that it examined the relationship between the investment committee's characteristics and corporate performance in the context of Saudi financial firms.

Studies in literature that have covered corporate governance characteristics mainly focused on board of directors, audit committee, ownership, and the like, but investment committee 
characteristics were largely ignored, as a result of which, studies dedicated to the latter are few and far between. Therefore, this gave the present study impetus to focus on the investment committee characteristics to contribute to and minimize the gap in literature of corporate governance.

The focus of this study was placed on the Saudi listed financial firms, as they constitute a sector representing the largest of its kind in the Arab and Gulf markets. It is also one of the top markets that are striving to appeal and attract investments from all over the world. This was mentioned in the Kingdom of Saudi Arabia's Vision 2030, aiming to transform the market into a global financial market. This justified the focus of this study.

The study is expected to contribute to companies, regulators, policy makers, and shareholders in the market of Saudi Arabia in several different ways. The first contribution is the provision of invaluable information to stakeholders, investors (current and potential) and the public at large. This will raise awareness of the companies' corporate governance characteristics and their role and impact on their performance.

The second contribution is to practice, particularly management of companies. Management should acknowledge the corporate governance characteristics in light of the diverse effects on company value. Such recognition will pave the way to selecting the most suitable strategy to be employed in the investment committee, while keeping the benefits of company value enhancement into consideration via enhanced management of the committee in all company types.

\section{Limitations and Suggestions for Future Studies}

Limitations highlighted in this study have to be taken into account when generalizing the findings to the population at large and when extending the study further in the future. The first limitation pertains to the examined direct relationship between investment committee characteristics and corporate performance of firms. Other characteristics could be added by future studies for comparison, like the characteristics of board of directors, of the audit committee, risk committee and other committees in their role in enhancing performance. The second study limitation is related to the focus on the financial firms, and as such, future studies can focus on their non-financial counterpart.

The third limitation is the duration of study (four years), and in this regard, future studies can examine the variables throughout more years for the purpose of generalization. The study is also limited to the choice of committee examined, whereby future studies could examine new committee remuneration, purchase committee, training committee and other new committees that have been under examined in literature in terms of their role in enhancing performance. The study adopted ROE to proxy the performance of financial firms, which was examined as the dependent variable. In future studies, other accounting measurements and market measurements may be adopted that could shed more light into firm performance.

\section{References}

Abdallah, A. A.-N., \& Ismail, A. K. (2017). Corporate Governance Practices, Ownership 


\section{$\triangle 1$ Macrothink}

International Journal of Accounting and Financial Reporting

ISSN 2162-3082

Structure, and Corporate Performance in the GCC Countries. Journal of International Financial Markets, Institutions and Money, 46, 98-1115.

Ahmed, E., \& Hamdan, A. (2015). The impact of corporate governance on firm performance: Evidence from Bahrain Bourse. International Management Review, 11(2), 21.

Al-Bassam, W. M., Ntim, C. G., Opong, K. K., \& Downs, Y. (2018). Corporate Boards and Ownership Structure as Antecedents of Corporate Governance Disclosure in Saudi Arabian Publicly Listed Corporations. Business \& Society, 57(2), 335-377.

Al-Hadi, A., Hasan, M. M., \& Habib, A. (2016). Risk committee, firm life cycle, and market risk disclosures. Corporate Governance: An International Review, 24(2), 145-170.

Al-Janadi, Y., Rahman, R. A., \& Alazzani, A. (2016). Does government ownership affect corporate governance and corporate disclosure?. Managerial Auditing Journal, 31(8/9), 871-890.

Al-Matari, E. M., Al-Swidi, A. K., \& Fadzil, F. H. B. (2014). The Measurements of Firm Performance's Dimensions. Asian Journal of Finance \& Accounting, 6(1), 1-24.

Al-Matari, E. M., Al-Swidi, A. K., Faudziah, H. B., Al-Matari, Y. A. (2012). The Impact of boardcharacteristicson Firm Performance: Evidence from Nonfinancial Listed Companies in Kuwaiti Stock Exchange. International Journal of Accounting and Financial Reporting, 2(2), 310-332.

Al-Matari, Y. A., Al-Swidi, A. K., Fadzil, F. H. B. F. H., \& Al-Matari, E. M. (2012). Board of Directors, AuditCommittee Characteristics and the Performance of Saudi Arabia Listed Companies. International Review of Management and Marketing, 2(4), 241-251.

Al-Obaidan, A. M. (2008). Market structure concentration and performance in the commercial banking industry of emerging markets. European Journal of Economics, Finance and Administrative Sciences, 12(1), 104-114.

Al-Rimawi, L. M. (2001). Jordanian, Kuwaiti and Omani Securities Regulation: Can they be Subject Matter of a Viable Comparative Study with EU Securities Regulation?. Journal of Financial Regulation and Compliance, 9(3), 253-273.

Baltagi, B. (2008). Econometric analysis of panel data (4th ed.). New York: John Wiley \& Sons.

Berle, A., \& Means, G. (1932). The Modern Corporation and Private Property. New York, $\mathrm{NY}$ : Macmillan.

Bhagat, S., \& Bolton, B. (2008). Corporate governance and firm performance. Journal of Corporate Finance, 14, 257-273.

Breusch, T. S., \& Pagan, A. R. (1979). A simple test for heteroscedasticity and random coefficient variation. Econometrica: Journal of the Econometric Society, 1287-1294.

Chaganti, R. S., Mahajan, V., \& Sharma, S. (1985). Corporate board size, composition and 
corporate failures in retailing industry. Journal of Management Studies, 22(4), 400-417.

Cook, R. D., \& Weisberg, S. (1983). Diagnostics for heteroscedasticity in regression. Biometrika, 70(1), 1-10.

Dallas, L. L. (2001). Developments in U.S. boards of directors and the multiple roles of corporate boards. Working Paper, University of San Diego.

Dalton, D. R., Daily, C. M., Ellstrand, A. E., \& Johnson, J. L. (1998). Meta-analytic reviews of board composition, leadership structure and financial performance. Strategic Management Journal, 19, 269-290.

Goodstein, J., Gautam, K., \& Boeker, W. (1994). The effects of board size and diversity on strategic change. Strategic Management Journal, 15(3), 241-250.

Gujarati, P. (2015). Basic Econometrics (5th ed.). New York: McGraw-Hill Education.

Hair, J. F., Anderson, R. E., Tatham, R. L., \& Black, W. C. (2010). Multivariate data analysis (2nd ed.). New York: Prentice-Hall, Upper Saddle River, NJ.

Hair, J. F., Black, W. C., Babin, B. J., \& Anderson, R. E. (2013). Multivariate Data Analysis (7th ed.). New Jersey: Pearson Education, Limited.

Herly, M., \& Sisnuhadi. (2011). Corporate governance and firm performance in Indonesia. International Journal of Governance, 1(2).

Hsu, W., \& Petchsakulwong, P. (2010). The impact of corporate governance on the efficiency performance of the thai non-life insurance industry. The Geneva Papers on Risk and Insurance Issues and Practice, 35(1), S28-S49.

Jackling, B., \& Johl, S. (2009). Board structure and firm performance: Evidence from India's top companies. Corporate Governance: An International Review, 17(4), 492-509.

Jensen, M. (1993). The modern industrial revolution, exit and the failure of internal control systems. Journal of Finance, 48, 831-880.

Jensen, M., \& Meckling, W. H. (1976). Theory of the firm: managerial behavior, agency costs, and ownership structure. Journal of Financial Economics, 3, 305-360.

Johnson, G. N., Scholes, J. D., Horton, P., \& Young, A. J. (1993). Relationships between carotenoid composition and growth habit in British plant species. Plant, Cell \& Environment, 16(6), 681-686.

Khanchel, I. (2007). Corporate governance: Measurement and determinant analysis. Managerial Auditing Journal, 22(8), 740-760.

Khatab, H., Masood, M., Zaman, K., Saleem, S., \& Saeed, B. (2011). Corporate governance and firm performance: A case study of Karachi stock market. International Journal of Trade, Economics and Finance, 2(1), 39.

Kyereboah-Coleman, A., \& Biekpe, N. (2006). The link between corporate governance and 
performance of the non-traditional export sector: Evidence from Ghana. Corporate Governance Journal, 6(5), 609-623.

Lipton, M., \& Lorsch, J. (1992). Modest proposal for improved corporate governance. Business Lawyer, 12(3), 48-59.

Mace, M. (1986). Directors: Myth and Reality. Boston: Harvard Business School Press.

Mersni, H., \& Ben Othman, H. (2016). The impact of corporate governance mechanisms on earnings management in Islamic banks in the Middle East region. Journal of Islamic Accounting and Business Research, 7(4), 318-348.

Nanka-Bruce, D. (2011). Corporate governance mechanisms and firm efficiency. International Journal of Business and Management, 6(5), 28-41.

NazliAnum, M. G. (2010). Ownership structure, corporate governance and corporate performance in Malaysia. International Journal of Commerce and Management, 20(2), 109-119.

Pearce, J. H., \& Zahra, S. A. (1992). Board composition from a strategic contingency perspective. Journal of Management Studies, 29(2), 411-438.

Pfeffer, J. (1972). Size and composition of corporate boards of directors: The organization and its environment. Administrative Science Quarterly, 218-228

Pfeffer, J. (1987). A resource dependence perspective on intercorporate relations. Intercorporate Relations: The Structural Analysis of Business, 25-55.

Provan, K. G. (1980). Board power and organizational effectiveness among human service agencies. Academy of Management Journal, 23(2), 221-236.

Quinonez, P., Saenz, J., \& Solorzano, J. (2018). Does foreign direct investment reduce poverty? The case of Latin America in the twenty-first century. BEH - Business and Economic Horizons, 14(3), 488-500.

Ramly, Z., \& Nordin, N. D. H. M. (2018). Sharia Supervision Board, Board Independence, Risk Committee and Risk-taking of Islamic Banks in Malaysia. International Journal of Economics and Financial Issues, 8(4), 290-300.

Rouf, D. (2011). Corporate characteristics, governance attributes and the extent of voluntary disclosure in Bangladesh. African Journal of Business Management, 5(19), 7836-7845.

Rouf, D. (2011). The relationship between corporate governance and value of the firm in developing countries: Evidence from Bangladesh. The International Journal of Applied Economics and Finance, 5, 237-244.

Salancik, G. R., \& Pfeffer, J. (1978). A social information processing approach to job attitudes and task design. Administrative Science Quarterly, 224-253.

Shaver, D. (2005). Characteristics of corporate boards in single-industry and conglomerate media companies. International Journal of Media Management, 7(3\&4), 112-120. 


\section{Macrothink}

International Journal of Accounting and Financial Reporting

ISSN 2162-3082 2019, Vol. 9, No. 4

Shivdasani, A., \& Zenner, M. (2002). Best practices in corporate governance: What two decades of research work?. New York: Salomon Smith Barney.

Stanwick, P. A., \& Stanwick, S. (2010). The relationship between corporate governance and financial performance: An empirical study of Canadian firms. The Business Review, 16(2), $35-42$.

Yermack, D. (1996). Higher market valuation of companies with a small board of directors. Journal of Financial Economics, 40(2), 185-211.

Zald, M. N. (1967). Urban differentiation, characteristics of boards of directors, and organizational effectiveness. American Journal of Sociology, 73(3), 261-272.

\section{Copyright Disclaimer}

Copyright for this article is retained by the author(s), with first publication rights granted to the journal.

This is an open-access article distributed under the terms and conditions of the Creative Commons Attribution license (http://creativecommons.org/licenses/by/4.0/) 